Article

\title{
Options to Continue the EU ETS for Aviation in a CORSIA-World
}

\author{
Sven Maertens * $\mathbb{C}$, Wolfgang Grimme, Janina Scheelhaase and Martin Jung
}

Institute of Air Transport and Airport Research, German Aerospace Center (DLR e.V.), 51147 Cologne, Germany; wolfgang.grimme@dlr.de (W.G.); janina.scheelhaase@dlr.de (J.S.); m.jung@dlr.de (M.J.)

* Correspondence: sven.maertens@dlr.de; Tel.: +49-2203-601-2596

Received: 3 September 2019; Accepted: 11 October 2019; Published: 15 October 2019

\begin{abstract}
From 2021, an increasing percentage of the carbon emission growth in international air transport will be subject to offsetting under the Carbon Offsetting and Reduction Scheme for International Aviation (CORSIA). Presently, it is still unclear if, and how, the existing EU emissions trading scheme (ETS) for aviation will continue. We assess the environmental impacts of different options (not) to continue with the EU ETS for aviation alongside CORSIA, and also discuss resulting monitoring, reporting, and verification (MRV) requirements. Our results indicate that any form of continuation of the EU ETS would have positive environmental effects especially in the early 2020s, when the coverage and environmental impact of CORSIA, which only tackles any post-2020 emission growth in international aviation, will still be low. If, moreover, a certain failure of CORSIA Certified Emission Reductions (CERs) to actually achieve emission reduction elsewhere is assumed, the environmental net benefit of CORSIA will be even lower. From both the policy and economic perspectives, these aspects may further strengthen the need to continue with the EU ETS for aviation. Possible options are to maintain the EU ETS in operation for domestic flights only, as a complement to CORSIA, or to keep it alive even for international flights within the European Economic Area (EEA), replacing CORSIA there as an equivalent measure. Another option to increase the environmental effectiveness of CORSIA, at least to some extent, could be to voluntarily extend it to domestic EEA flights. Administrative-wise, the CORSIA MRV system could be applied to a continued EU ETS to reduce transaction costs and to assure globally similar or even identical MRV standards, e.g., with regard to exemptions and eligible fuel monitoring methods.
\end{abstract}

Keywords: air transport emissions; climate impact; EU ETS; CORSIA; emissions trading; MRV; offsetting

\section{Introduction}

In 1992, civil aviation (hereinafter also referred to as air transport) represented some $2 \%$ of total anthropogenic carbon dioxide $\left(\mathrm{CO}_{2}\right)$ emissions, or about $13 \%$ of all transport-related $\mathrm{CO}_{2}$ emissions [1]. The sector's $\mathrm{CO}_{2}$ emissions subsequently rose at average rates of $1.8 \%$ per year until 1999 , and of $2.1 \%$ per year until 2005, respectively, resulting in slightly increasing shares of total anthropogenic $\mathrm{CO}_{2}$ emissions [2]. Counting only international aviation activities, the 2017 release of the International Energy Agency database " $\mathrm{CO}_{2}$ Emissions from Fuel Combustion" indicates total $\mathrm{CO}_{2}$ emissions from fuel combustion of 32,294 million tons for the year 2015, including some 529.7 million tons (or 1.6\%) from international air transport [3]. Moreover, aviation's total contribution to radiative forcing and, by this, to anthropogenic climate change, stems not only from the sector's $\mathrm{CO}_{2}$ emissions, but also from other gases and particulates like $\mathrm{NO}_{\mathrm{X}}, \mathrm{SO}_{\mathrm{X}}, \mathrm{H}_{2} \mathrm{O}$, or soot. Considering this, Lee et al. estimated air transport to have contributed about $4.9 \%$ to man-made radiative forcing in 2005 [2]. 
As air transport continues to grow at enormous pace, with no substantial departure from fossil fuels in sight, the sector's emissions and resulting climate impacts are likely to further increase. For instance, Airbus Industries expects an average worldwide growth in revenue passenger kilometers (RPK) of about $4.4 \%$ p.a. until 2037 [4].

Two international market-based measures have been designed and introduced to help reducing the sector's carbon footprint, and, ultimately, reaching the UNFCCC 1.5/2.0 degrees goals [5]. One is the EU Emissions Trading Scheme (EU ETS), which was extended to aviation in 2012. The other one is the Carbon Offsetting and Reduction Scheme for International Aviation (CORSIA), which was agreed on at the 39th International Civil Aviation Organization (ICAO) Assembly in 2016 after decades of difficult international negotiations. In full operation from 2021, CORSIA shall cover an increasing number of states. Both schemes aim at reducing the net climate impact of aviation as airlines have to surrender allowances (EU ETS) or offsets (CORSIA) for certain shares of their $\mathrm{CO}_{2}$ emissions, both representing $\mathrm{CO}_{2}$ reduction elsewhere.

However, the actual geographical scope and environmental effectiveness of the two schemes differ considerably. In its present form, the EU ETS for aviation is limited to flights within the European Economic Area (EU Member States, Iceland, Liechtenstein, Norway; short: EEA), including domestic flights. Its cap is defined as $95 \%$ of the average historical emissions of the years 2004-2006, i.e., the airline sector is required to buy allowances for all emissions exceeding this level. In contrast, CORSIA will be applied to international flights between participating states, while domestic flights are excluded. In addition, its baseline is less strict as airlines will have to surrender offsets for emissions exceeding average 2019/2020 levels only, and there are serious concerns about the offsets' environmental integrity. Against this background, the EU will have to decide if, and how, to continue with the EU ETS for aviation-especially with regard to international intra-EEA flights which are, as matters stand, subject to both schemes.

In this paper, we assess the environmental impacts of different options of continuing or not continuing with the EU ETS, and also briefly discuss resulting requirements for monitoring, reporting, and verification (MRV). Section 2 contains a literature analysis on the genesis and key provisions of the EU ETS for aviation and CORSIA, as well as the key differences between the two approaches. In Section 3, by applying region-pair specific growth factor estimates to a matrix of modeled $\mathrm{CO}_{2}$ emissions at the route level, we calculate future air transport emissions and investigate the emissions net reductions of different political options to fully or partly (dis)continue the EU ETS alongside CORSIA. In addition, we briefly introduce and discuss the two schemes' MRV requirements and resulting administrative efforts associated with each of these options. Section 4 concludes this paper.

\section{EU ETS vs. CORSIA}

\subsection{Genesis, Key Functioning, and Impacts of the EU ETS for Aviation}

Neither the 2015 Paris Agreement by the UN Framework Convention on Climate Change [5] nor the 1997 Kyoto Protocol [6] do explicitly provide provisions for the limitation of air transport emissions. However, in the Kyoto Protocol, the International Civil Aviation Organization (ICAO) was tasked to prepare policy measures for the reduction of greenhouse gas emissions (GHG) from aviation [6]. This marked the starting point of a long-lasting political process which eventually resulted in the October 2016 Assembly Resolution A39-3 on CORSIA [7].

However, reacting to slow progress at ICAO level [8], the EU had already introduced the EU ETS for aviation, its own, regional market-based measure regulating $\mathrm{CO}_{2}$ emissions from Community air transport. Initial legal frameworks for the EU ETS for aviation were the EU Directives 2008/101/EC [9] and 2009/29/EC [10].

The key functioning of the EU ETS for aviation is described in, e.g., [11], [12], and in a number of earlier papers, like [13] or [14], and illustrated in Figure 1. 


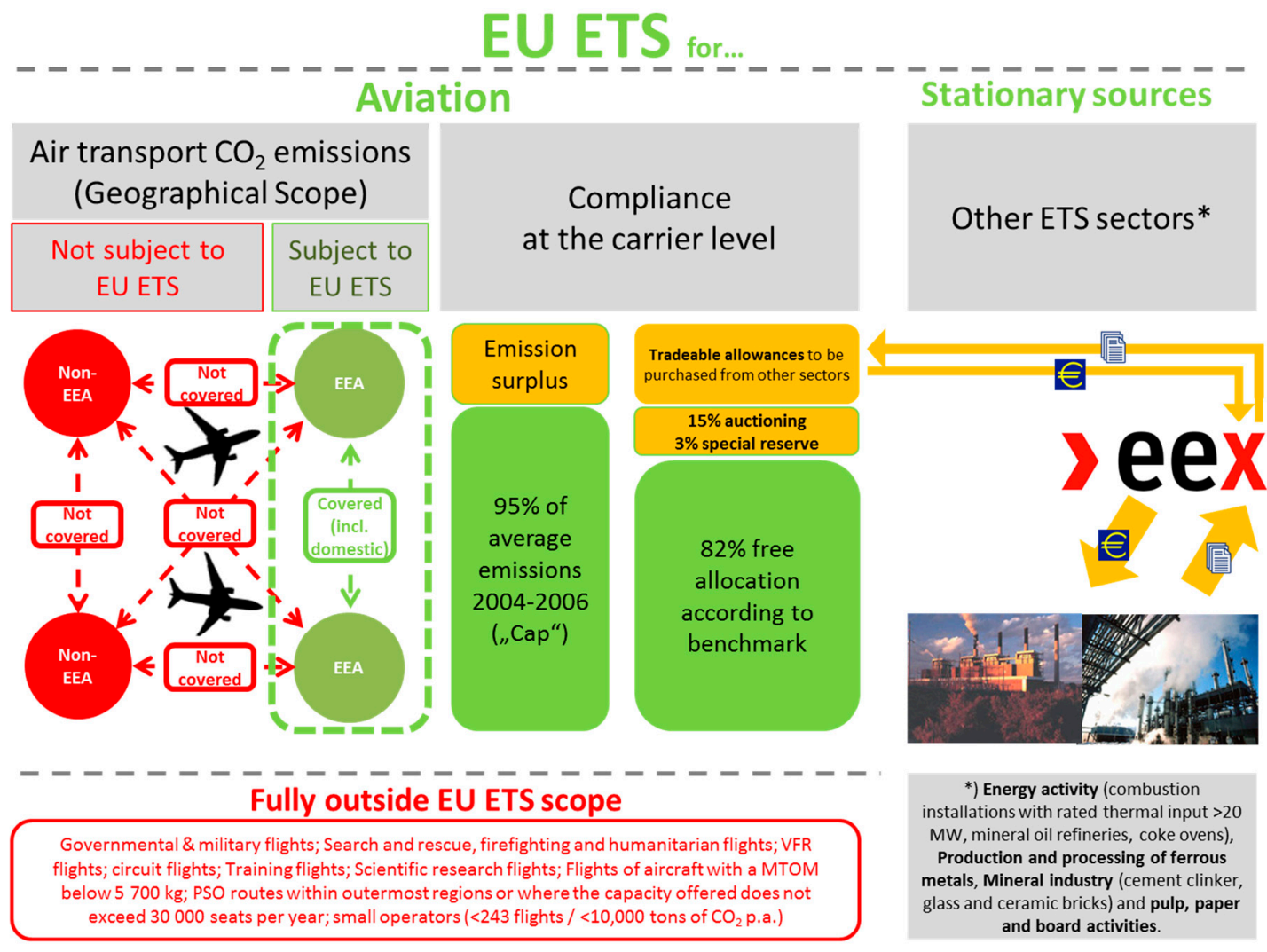

Figure 1. Design of the EU Emissions Trading Scheme (EU ETS) for aviation. Own figure based on information from European Commission websites and legislations. Pictures taken from ec.europa.eu. Eex logo taken from eex.com.

In brief, the EU ETS keeps net $\mathrm{CO}_{2}$ emissions from European air transport below average "historical" 2004-2006 levels, the so-called "cap". For this, on an annual basis, tradable allowances representing one ton of $\mathrm{CO}_{2}$ each, which-in total-do not exceed the cap, are allocated to aircraft operators according to a certain benchmark and must be surrendered according to the carriers' actual emissions. Any additional allowances have to be purchased from other airlines or stationary sources participating in the scheme, whereby EU Allowances (EUA) and permits from the Kyoto-based "Clean Development Mechanism" (CERs) and "Joint Implementation" (ERUs) are up to certain levels accepted for compliance. This way, annual air transport emissions beyond 2004-2006 levels are compensated as the same amount of emissions is reduced elsewhere. Due to the actual cap, the environmental effectiveness of EUAs can be regarded as almost 100\%, while, e.g., the effectiveness of CERs depends on requirements such as additionality (see also Section 2.3).

To be more precise, until 2020, the cap is defined as 95\% of average historical 2004-2006 emissions, of which $82 \%$ are allocated for free, with the remaining ones auctioned $(15 \%)$ or allocated to a special reserve (3\%) for later distribution to fast growing airlines and new entrants [15]. From 2021, as with the EU ETS for stationary sources, a linear reduction factor of $2.2 \%$ will help further reducing the cap from year to year in order to meet the EU2030 climate goals [16].

Originally, almost all flights from or to EEA airports were planned to be subject to the EU ETS ("full scope"), except for some "de-minimis" provisions for certain flights performed under public service obligations (PSO), or for aircraft operators with annual $\mathrm{CO}_{2}$ emissions below 10,000 tons. However, in a response to strong international opposition and to ease the ongoing CORSIA negotiations at ICAO level $[17,18]$, the EU's "stop the clock" decision eventually reduced the scheme's scope to intra-EEA traffic [19]. The resulting "stop the clock" or "reduced scope" regime was originally planned to last until 2016 only. However, by regulation (EU) 2017/2392 and to allow for a review of the CORSIA implementation, the EU decided to maintain this framework until 31 December 2023. In case of 
no revision, the regulation would provide for a return to the original, full scope regime from 2024 onwards $[12,16]$.

The impacts of the EU ETS for aviation were assessed in a number of publications. Anger and Köhler reviewed ex-ante studies on the scheme's environmental and economic effects, which all papers analyzed found to be small with expected single-digit emission reductions and almost no $(-0.002 \%)$ GDP impact [13]. Preston et al. assessed the global coverage of the original and reduced EU ETS regimes, respectively [8]. They found that, as a result of the "stop the clock" decision, the share of worldwide emissions regulated by the EU scheme declined from $35 \%$ to a small double-digit figure. Papers from the airline perspective, assessing ETS-related costs for the carriers, include research from Albers et al. who expected the scheme's likely cost effects to be rather small (between $€ 9$ and $€ 27$ per route for carbon prices of $€ 20$ per ton) and therefore unlikely to stimulate network reconfigurations [20]. A relatively new issue is a potential consideration of non- $\mathrm{CO}_{2}$ effects within market-based measures like the EU ETS, which would result in much larger cost effects depending on the length, route, and altitude of each flight [21].

\subsection{Introduction and Design of CORSIA}

Almost 20 years after Kyoto, the 39th ICAO Assembly eventually adopted Resolution A39-3 on a formalized GMBM system in the form of the offsetting scheme CORSIA, aiming at supporting the goal of carbon neutral growth in international aviation from 2020 onwards ("CNG 2020").

Under CORSIA, subject to some exceptions, the air transport sector will be obliged to offset its post-2020 growth in $\mathrm{CO}_{2}$ emissions on international routes by purchasing carbon credits from, or by investments in projects that help reducing carbon emissions in other sectors with a higher potential and lower cost for quicker reductions. Tradable certificates or permits representing the right to emit one ton of carbon dioxide or its equivalent, so-called "carbon credits", will be used for compliance. Consequently, airlines are expected to offset their emissions whenever this is cheaper than to reduce them directly.

The carbon credits which will be accepted for compliance shall arise from emission reduction mechanisms (such as UNFCCC's Clean Development Mechanisms CDM), programs, or projects which, in return, are supposed to deliver measurable reductions in emissions [18]. This way, ICAO aims at freezing international aviation's net $\mathrm{CO}_{2}$ emissions at 2020 levels, while the other emissions reduction measures like new technologies, the use of alternative fuels, or operational and infrastructural improvements shall be further pursued. Operational and infrastructural improvements are not unlikely to actually generate traffic growth, though, which may even increase the need for an effective market-based measure.

Based on Assembly Resolution A39-3 and the related Standards and Recommended Practices (short: SARPs) "Annex 16 to the Convention on Civil Aviation, Vol. IV" [22], Figure 2 depicts how CORSIA works.

Firstly, worldwide air transport is split into flights within and outside of CORSIA's scope, respectively. Emissions from domestic flights are covered by the UNFCCC Paris Agreement and do not fall under CORSIA [23]. Moreover, ICAO is only responsible for international air traffic. In addition, emissions from domestic flights, but also emissions from small operators $\left(<10,000 \mathrm{t} \mathrm{CO}_{2}\right.$ p.a.), from small aircraft $(<5.7 \mathrm{t}$ MTOM), and rotorcraft, and from humanitarian, medical, and firefighting operations do not fall under the scheme (Assembly Resolution A39-3, §13). Military and governmental aviation is fully excluded as it is not subject to the Chicago Convention. 


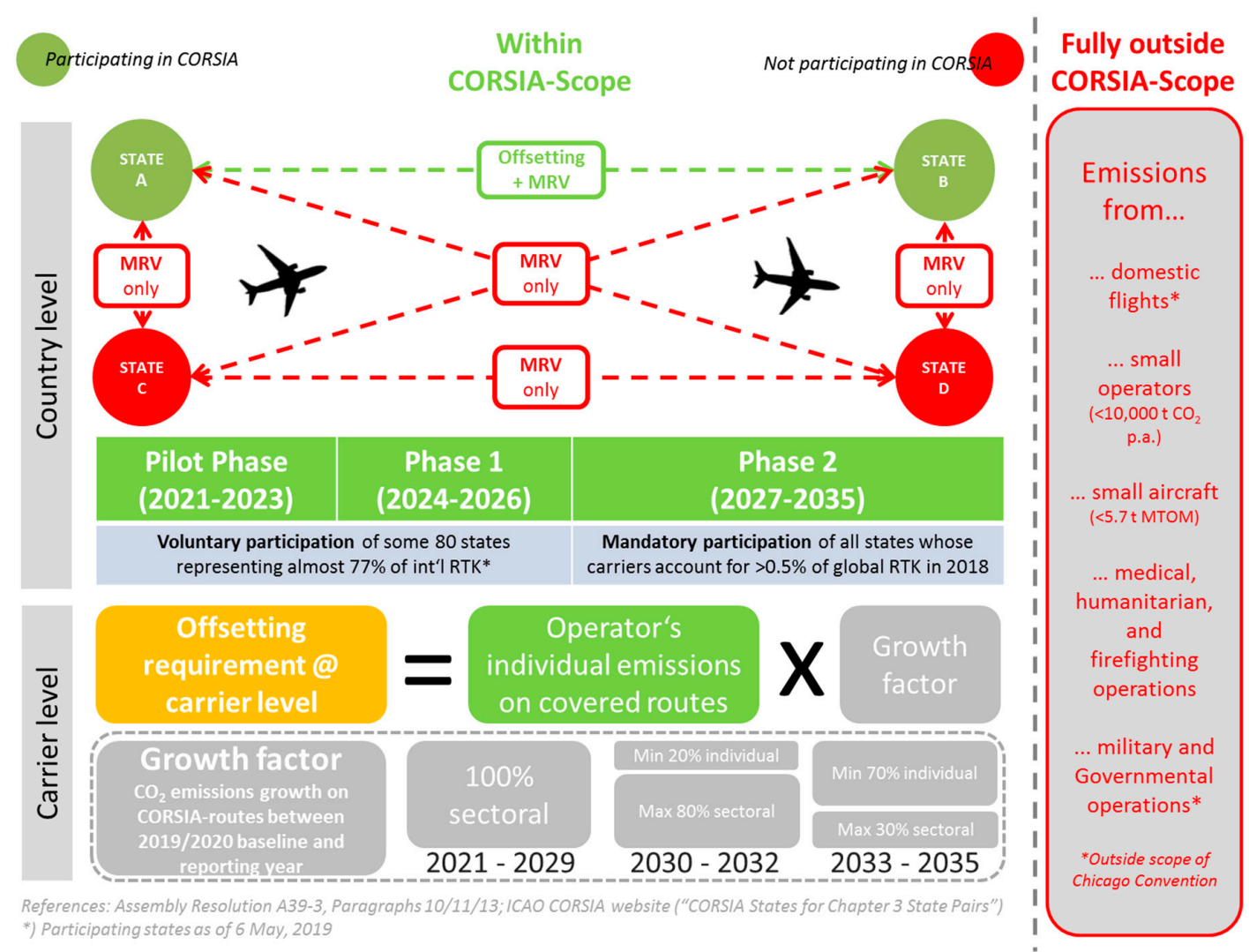

Figure 2. Design of the Carbon Offsetting and Reduction Scheme for International Aviation (CORSIA). Own Figure based on [7], Paragraphs 10/11/13, and [24].

In contrast, all other emissions from international air transport are, in principle, subject to the scheme. However, actual offsetting requirements will only apply to emissions from flights between participating states ("CORSIA-states") (\$10a). While emissions from flights between CORSIA-states and non-CORSIA-states, or entirely between non-CORSIA-states, will not be subject to offsetting, they still have to be monitored, reported, and verified $(\S 10 b, \S 10 \mathrm{c})$ according to the internationally uniform standards of Annex 16, Volume IV.

In other words, actual offsetting requirements of any airline in the world will solely depend on actual emissions on routes between participating CORSIA-states, while the remaining emissions from international flights will still have to be monitored, reported, and verified.

Offsetting under CORSIA starts in 2021 and consists of three phases: Pilot Phase (2021-2023), Phase 1 (2024-2026), and Phase 2 (2027-2035).

In the Pilot Phase and in Phase 1, participation in the scheme will be voluntary (§9a, §9b). From 2027, participation in CORSIA will be mandatory for all states except for small islands, least developed countries, land-locked developing countries, and states whose carriers have accounted for less than $0.5 \%$ of international RTK in 2018, unless they volunteer ( $\$ 9$ e).

As per July 2019, 80 states whose carriers represent about $77 \%$ of international revenue ton kilometers (RTK) have announced they will voluntarily participate from scratch (see Table 1). This list includes not only the EU states and other big players like Australia, Canada, Indonesia, Korea, Japan, Mexico, Qatar, Turkey, the UAE, and the US, but also smaller or developing states like Armenia, Botswana, Jamaica, or Zambia. The largest countries missing on the list are the BRIC-states Brazil, Russia, India, and China. 
Table 1. Voluntarily participating CORSIA states (as of 15 July 2019).

\begin{tabular}{llll}
\hline 1. Albania & 22. Estonia & 44. Malaysia & 66. Serbia \\
2. Armenia & 23. Finland & 45. Malta & 67. Singapore \\
3. Australia & 24. France & 46. Marshall Islands & 68. Slovakia \\
4. Austria & 25. Gabon & 47. Mexico & 69. Slovenia \\
5. Azerbaijan & 26. Georgia & 48. Monaco & 70. Spain \\
6. Belgium & 27. Germany & 49. Montenegro & 71. Sweden \\
7. Bosnia and Herzegovina & 28. Ghana & 50. Namibia & 72. Switzerland \\
8. Botswana & 29. Greece & 51. Netherlands & 73. Thailand \\
9. Bulgaria & 30. Guatemala & 52. New Zealand & 74. Turkey \\
10. Burkina Faso & 31. Guyana & 53. Nigeria & 75. Uganda \\
11. Cameroon & 32. Hungary & 54. North Macedonia & 76. Ukraine \\
12. Canada & 33. Iceland & 55. Norway & 77. United Arab Emirates \\
13. Costa Rica & 34. Indonesia & 56. Papua New Guinea & 78. United Kingdom \\
14. Croatia & 35. Ireland & 57. Philippines & 79. United States \\
15. Cyprus & 36. Israel & 58. Poland & 80. Zambia \\
16. Czech Republic & 37. Italy & 59. Portugal & \\
17. Democratic Republic of & 38. Jamaica & 60. Qatar & \\
Congo & 39. Japan & 61. Republic of Korea & \\
18. Denmark & 40. Kenya & 62. Republic of Moldova & \\
19. Dominican Republic & 41. Latvia & 63. Romania & \\
20. El Salvador & 42. Lithuania & 64. San Marino & \\
21. Equatorial Guinea & 43. Luxembourg & 65. Saudi Arabia & \\
\hline
\end{tabular}

Source: [24].

From 2021, when actual offsetting under CORSIA starts, the airline sector will be required to compensate any emissions from "CORSIA-flights" which exceed the average emissions from CORSIA-routes in 2019 and 2020 ("baseline"). For the baseline calculation by ICAO, all ICAO contracting states are obliged to report their carriers' route-level RTK and emissions for 2019 and 2020. Whenever additional countries join CORSIA in the future, the baseline will have to be amended accordingly.

Actual offsetting occurs at the carrier level, under supervision of the responsible competent authority. To calculate an airline's offsetting obligation for the reporting years 2021 to 2029, its individual emissions from CORSIA-routes have to be multiplied by the sectoral emission growth rate (over all carriers) on CORSIA-routes since the baseline period (\$11).

Example: Airline A's emissions on CORSIA routes amount to 4,912,000 tons of $\mathrm{CO}_{2}$ in 2021. The airline sector's emission growth on CORSIA-routes between the baseline period and 2021 is $3.8 \%$. Airline A's offsetting requirement for 2021 is calculated as: 4,912,000 $\times 0.038=186,656$ tons of $\mathrm{CO}_{2}$.

The idea behind applying the average sectoral mission growth uniformly to all carriers in the early years is a political compromise in an attempt to achieve the right balance between the offsetting requirements for established and younger carriers, respectively. Otherwise, young and fast-growing airlines, like the $\mathrm{ChiBoGu}$ (the abbreviation $\mathrm{ChiBoGu}$ refers to fast-growing carriers from China, Bosporus and the Gulf region) or many low cost carriers, would have to offset considerable shares of their emissions, while the more established, usually slower growing or stagnating, carriers would only have moderate offsetting obligations. From 2030, however, the individual emission growth will be considered to an increasing extent. New entrants are exempted from any offsetting obligations for a period of up to three years, provided that their annual emissions do not surpass $0.1 \%$ of global emissions in 2020 at an earlier point (\$12).

Early publications on CORSIA were published by the law firm Reed Smith Client and by CE Delft. The former gave an initial overview of the scheme and its geographical scope and exemptions. In addition, they discussed the implications of criteria for eligible offsets, as well as potential strategies for the EU ETS [25]. Based on an early assumption of 66 voluntarily participating states for the period 2021-2026, CE Delft compared the share of covered emissions with the EU ETS in its original and 
reduced scope regimes and found that some $81.5 \%$ of international air transport emission growth would be subject to offsetting [26].

In one of the first peer-reviewed journal papers on CORSIA, the scheme's expected environmental and competitive effects were compared with the EU ETS [27]. The authors expect CORSIA to initially (in 2021) cause a small net reduction of just $1.4 \%$ of global air transport $\mathrm{CO}_{2}$ emissions only, compared to about $2.1 \%$ for the EU ETS. However, the CORSIA impact will quickly grow to, e.g., $12 \%$ in 2030 . The authors further show that, due to its global approach with only few exceptions, the competitive effects on airlines will be smaller for CORSIA than for the EU ETS.

\subsection{Key Similarities and Differences}

As 'market-based measures', emission trading and offsetting schemes have an advantage over traditional 'command and control' politics because they ensure the achievement of pre-defined environmental targets in a cost-efficient manner. In putting (directly or indirectly) a price tag on emissions, producers are incentivized to reduce their negative externalities the most cost-effective way [27]. Table 2 summarizes the key differences between the EU ETS for aviation and CORSIA.

Table 2. Key characteristics of CORSIA and the EU ETS.

\begin{tabular}{|c|c|c|c|}
\hline \multicolumn{2}{|c|}{ Scheme } & EU ETS & CORSIA \\
\hline \multirow{3}{*}{ Fundamental differences } & Methodology & Cap \& Trade & Baseline \& Credit (Offsetting) \\
\hline & Environmental integrity & $\begin{array}{l}\text { Not critical, overall cap is } \\
\text { fixed }\end{array}$ & $\begin{array}{l}\text { Dependent on offset quality } \\
\text { standards and enforcement }\end{array}$ \\
\hline & $\begin{array}{l}\text { Need for verification by } \\
\text { authorities }\end{array}$ & Only at emitter level & $\begin{array}{l}\text { Both at emitter and at offsetting } \\
\text { project level }\end{array}$ \\
\hline \multirow{4}{*}{$\begin{array}{c}\text { Differences in actual } \\
\text { implementation and } \\
\text { application (coverage \& } \\
\text { baseline) }\end{array}$} & Cap/Baseline & $\begin{array}{l}95 \% \text { of avg. } 2004 / 2006 \\
\text { emissions; stepwise further } \\
\text { reduction of cap envisaged }\end{array}$ & $\begin{array}{l}\text { Avg. } 2019 / 2020 \text { emissions; no } \\
\text { further reduction envisaged }\end{array}$ \\
\hline & Scope & $\begin{array}{l}\text { Intra-EEA including } \\
\text { domestic flights }\end{array}$ & $\begin{array}{l}\text { International routes between } \\
\text { participating states }\end{array}$ \\
\hline & Affected carriers & \multicolumn{2}{|c|}{ All airlines operating on covered routes, unless exceptions apply } \\
\hline & Affected aircraft Types & $\begin{array}{c}\text { Fixed wing (>5.7 t MTOM) } \\
\text { and helicopters }\end{array}$ & Fixed wing (>5.7 t MTOM) \\
\hline
\end{tabular}

Both schemes aim at reducing the net climate impact of aviation as airlines have to surrender allowances (EU ETS) or offsets (CORSIA) for certain shares of their $\mathrm{CO}_{2}$ emissions which represent $\mathrm{CO}_{2}$ reductions elsewhere. Under the EU ETS, emissions from stationary installations (heat and power supply, as well as certain industries) and aircraft operators are capped, and producers of additional emissions have to buy excess allowances from other polluters participating in the scheme, unless it would be cheaper for them to reduce own emissions directly. CORSIA has no cap but a baseline and obliges carriers to compensate a certain percentage of emissions in buying offsets from eligible projects, like reforestation, which also represent a reduction of emissions elsewhere.

In theory, both schemes may reach a similar environmental effectiveness, as it does not matter if total emissions are capped to a certain level, or if emissions exceeding a certain baseline are compensated by emission reductions elsewhere. However, the environmental effectiveness of CORSIA will strongly depend on the integrity of the mechanisms, programs, and projects which generate the supply of available offsets. Although the Paris Agreement does not explicitly refer to aviation, the agreement's principles (article 6) for internationally transferred mitigation, like environmental integrity, transparency, and robust accounting, will also be critical for CORSIA [5].

On a global level, different carbon offset markets and quality assurance standards for carbon offsetting exist, like for instance the Gold Standard [28], which promise high environmental effectiveness. Criteria include (see, e.g., [29]) "additionality", i.e., a reduction of emissions elsewhere will actually be achieved and compensate additional emissions from the aviation sector. 
When CORSIA was agreed on in 2016, exact provisions regarding its implementation and eligible offsets were still subject to negotiations. In the meantime, eligibility criteria for CORSIA emission units were approved by the ICAO Council in March, 2019. The Council also agreed on the implementation of a Technical Advisory Body (TAB) which will consist of experts nominated by Member States and recommend eligible emission units against these criteria to the Council [30].

However, reservations against CORSIA remain. Apart from the not very ambitious baseline, it is argued that missing additionality may lead CORSIA to absurdity as most offsetting projects would have occurred anyway (for an overview of arguments see, e.g., [31,32], and the references cited there). Against this background, there is a high likelihood that only a relatively small percentage of the nominal emission reduction will actually be achieved when investing in CORSIA CERs. For example, Cames et al. (2016) assessed the current CDM framework with regard to its environmental integrity, i.e., to what extent projects are additional and resulting emission reductions not overestimated. The authors found that "73\% of the potential 2013-2020 Certified Emissions Reduction (CER) supply have a low likelihood" and that only "7\% of potential CER supply have a high likelihood of ensuring that emission reductions are additional and ... not over-estimated" [33].

In this context, there is also a second fundamental disadvantage of offsetting schemes like CORSIA compared to emission trading schemes, as MRV will have to be undertaken not only at the emitter level (i.e., in this case with the airlines), but also at the sources of emission reduction, i.e., at the mechanism, program, and project levels. This is likely to increase overall transaction costs.

In addition, the actual scope and baseline of CORSIA are different to the EU ETS for aviation. Geographically-wise, CORSIA has a larger scope, as a large share of international routes will be covered, even though domestic aviation is not affected. Until 2026, emissions from routes between $\sim 80$ states representing about $77 \%$ of international RTK will be subject to CORSIA, and this share is supposed to rise significantly in 2027 when the BRIC states and some other countries with noteworthy aviation activities will have to join. As a consequence, we estimate $35.7 \%$ of worldwide air transport $\mathrm{CO}_{2}$ emissions in 2021 and $52 \%$ in 2027 to fall under the scope of CORSIA, compared to just $8 \%$ for the EU ETS (Table 3-our methodology and data used will be presented in Section 3).

Table 3. Air transport emissions from flights on routes subject to CORSIA and the EU ETS.

\begin{tabular}{ccccc}
\hline Years & $\mathbf{2 0 2 1}$ & Share of Total & $\mathbf{2 0 2 7}$ & Share of Total \\
\hline Total emissions (Mt) & 887.0 & $100.0 \%$ & 1080.6 & $100.0 \%$ \\
\hline of which subject to CORSIA & 316.6 & $35.7 \%$ & 561.9 & $52.0 \%$ \\
\hline of which subject to EU ETS & 72.3 & $8.1 \%$ & 84.5 & $7.8 \%$ \\
\hline \multicolumn{4}{c}{ Source: Own estimations (for the calculation methodology please refer to Section 3). }
\end{tabular}

However, the general scope of CORSIA is only one side of the story, as the two schemes also differ with regard to their baseline/cap, above which the sector has to actually surrender offsets or allowances. As explained in Sections 2.1 and 2.2, respectively, the baseline of the EU ETS is 95\% of average 2004-2006 emissions, while CORSIA will only require compensation of future annual emissions exceeding the 2019-2020 average. Hence, actual amount of emissions subject to offsetting or trading (see Section 3) is much smaller than the coverage shares from Table 3.

\section{Assessment of Options to Maintain the EU ETS in a CORSIA World}

\subsection{Range of Policy Options}

Very soon, the EU will have to decide how to continue with the EU ETS from the beginning of the CORSIA pilot offsetting phase. In this context, the question of how to deal with international intra-EU flights can be regarded as most crucial. According to Annex 16, Vol. IV, this issue seems clear: All EU states have agreed to join CORSIA from scratch, which regulates all international routes 
between participating states. Hence, emissions from international intra-EU flights are clearly subject to offsetting under CORSIA.

However, the EU may wish not to narrow the EU ETS to domestic intra-EU flights, let alone to stop it completely. For instance, in the last legislative period, the European Parliament already described CORSIA as not sufficiently ambitious and took the position that, in any case, intra-European flights would have to remain part of the EU ETS [18].

Furthermore, the Commission's delegated regulation for the implementation of CORSIA [34] indicates that the EU will not implement CORSIA in full accordance with Annex 16, Volume IV, but maintain elements of the EU ETS. For example, certain emissions subject to CORSIA seem to become exempted (like, e.g., search and rescue and training flights, or flights under visual flight or public service obligation rules), and MRV for emissions of EU carriers on CORSIA-routes outside the EEA is likely to become optional for EU-based airlines.

Scheelhaase et al. [27] already briefly discussed possible political options (and resulting transaction cost) for the timeframes 2018-2020 and 2021-2035, but also considered a revival of the full-scope approach of the EU ETS which, from today's perspective, seems rather unlikely as international opposition would be immense. On behalf of the European NGO 'Transport and Environment', Van Velzen [35] assessed the environmental impact of different combinations of the EU ETS and CORSIA quantitatively by applying the AERO-MS model [36]. He basically assessed two scenarios, one where the EU ETS is kept for domestic EU flights only, with CORSIA being applied to all international flights, and one where the EU ETS is being maintained in its current form and where CORSIA is used for international flights to extra-EEA countries only. He further introduced two variants: One variant would require airlines to surrender EUA (from the EU ETS system) also under CORSIA for emissions from international flights departing from the EU. The rationale behind this is that only this way would there be a contribution of international EU air transport to the EU emission target for 2030 since, otherwise, CORSIA offsets may stem from projects in non-EU territories. The other variant, which applies only to international intra-EEA flights in the second scenario, would be to use EUAs for emissions above the EU ETS cap which are not covered by international credits (i.e., for the growth between the EU ETS cap and the CORSIA baseline) and CORSIA for emissions above the CORSIA baseline.

Based on most recent information on CORSIA participation, we provide an updated, broader overview of possible options and estimate the resulting environmental effects in terms of emission net reduction, followed by a brief comment on the implications for MRV. For all options, we assume only one of the two market-based measures to be applied in each route group (intra-EEA domestic; intra-EEA international; EEA-RoW (Rest of the world); RoW-RoW international) at the same time, i.e., we suppose that there will be no double-regulation of the same emissions. We also assume that any continuation of the EU ETS would, as it was until now, refer to the scheme's reduced (=intra-EEA) scope or to domestic routes only, but not to the full-scope regime as originally envisaged. We further consider and model the linear reduction factor of 2.2\% p.a. which shall be applied to the EU ETS for aviation cap from 2021 according to Regulation (EU) 2017/2392. This way, we differentiate between the following four options which are summarized in Table 4:

1. Implementation of CORSIA as planned and discontinuation of the EU ETS ("CORSIA only");

2. Implementation of CORSIA as planned and continuation of the EU ETS for domestic flights only ("CORSIA + EU ETS domestic");

3. Voluntary extension of CORSIA to domestic EEA flights and discontinuation of the EU ETS ("CORSIA also for EEA domestic");

4. Application of CORSIA to flights partly or fully outside the EEA only and full continuation of the reduced (=intra-EEA) scope of the EU ETS ("EU ETS for intra-EEA und CORSIA for RoW"). 
Table 4. Options for the EU ETS alongside CORSIA.

\begin{tabular}{|c|c|c|c|c|c|}
\hline Route Group & $\begin{array}{c}\text { Intra-EEA } \\
(\text { domestic } * *)\end{array}$ & $\begin{array}{l}\text { Intra-EEA } \\
\text { (int'1) }\end{array}$ & EEA-RoW & $\begin{array}{l}\text { RoW-RoW } \\
\text { (int'l) }\end{array}$ & $\begin{array}{c}\text { RoW } \\
\text { (domestic) } * *\end{array}$ \\
\hline Sample country-pairs & $\begin{array}{c}\text { Intra-Italy } \\
\text { Intra-Norway }\end{array}$ & $\begin{array}{l}\text { Poland-Belgium } \\
\text { Spain-Norway }\end{array}$ & $\begin{array}{l}\text { France-Japan } \\
\text { Norway-USA }\end{array}$ & $\begin{array}{l}\text { USA-Canada } \\
\text { UAE-Ghana }\end{array}$ & $\begin{array}{l}\text { Intra-USA } \\
\text { Intra-China }\end{array}$ \\
\hline $\begin{array}{l}\text { Option } 1 \text { "CORSIA } \\
\text { only" }\end{array}$ & - & CORSIA & CORSIA * & CORSIA * & - \\
\hline $\begin{array}{c}\text { Option } 2 \text { "CORSIA + } \\
\text { EU ETS for EEA } \\
\text { domestic" }\end{array}$ & EU ETS & CORSIA & CORSIA * & CORSIA * & - \\
\hline $\begin{array}{l}\text { Option } 3 \text { "CORSIA } \\
\text { also for EEA domestic" }\end{array}$ & CORSIA & CORSIA & CORSIA * & CORSIA * & - \\
\hline $\begin{array}{l}\text { Option } 4 \text { "EU ETS for } \\
\text { intra-EEA \& CORSIA } \\
\text { for RoW" }\end{array}$ & EU ETS & EU ETS & CORSIA * & CORSIA * & - \\
\hline
\end{tabular}

* Until 2026: Only between voluntarily participating countries; from 2027: Only between countries whose carriers have accounted for a worldwide int'l RTK share of more than $0.5 \%$ in 2018 , plus any volunteers. ${ }^{* *}$ Domestic emissions are in principle covered of the UNFCCC Paris Agreement, which requires states to act.

\subsection{Quantification of the Options' Environmental Impacts}

\subsubsection{Methodology and Data}

The bases for our estimation of the environmental impacts of the options shown above are a modeling methodology already applied in [27], air schedule data, and most recent information on CORSIA participation.

First, we forecast global passenger traffic development and resulting $\mathrm{CO}_{2}$ emissions at the route level for the timeframe up to 2039. Starting point for this is the global passenger flight plan for the year 2016, as published by Innovata. Cargo flights could not be considered due to the poor data quality and limited coverage.

As a second step, the subsequent traffic growth until 2039 is modeled on the basis of ICAO-CAEP-FESG's 'Central' scenario [37] in increasing the frequencies on each route by the route-specific growth rate estimate.

In a next step, the DLR's 4D RACE emission tool is applied to the schedule lists to model related, route-specific $\mathrm{CO}_{2}$ emissions considering an average autonomous fuel efficiency increase of $1.2 \%$ p.a. We are aware that this approach implies the route structure to remain constant as the ICAO-CAEP growth rates are translated into frequency increases on existing routes and not into new routes. However, from a global emissions perspective, it is less important whether frequencies on an existing route (e.g., Düsseldorf to Palma de Mallorca) increase or new flights on a similar route within the same geographical route-group are inaugurated (e.g., Amsterdam to Malaga).

Finally, in an Excel-based tool, we filter the route-level $\mathrm{CO}_{2}$ estimates according to the policy options presented above, and apply the individual schemes' base-lines/caps to calculate the amount and share of annual emissions covered by each option, as well as the accumulated emissions.

\subsubsection{Results and Discussion-Annual Emission Reduction by Option}

For the period from 2016 to 2035, we expect an average annual growth in global air transport $\mathrm{CO}_{2}$ emissions of about $3.3 \%$ p.a. In absolute terms, this would result in a $\mathrm{CO}_{2}$ emission increase from about 734 million tons in 2016 to some 1,363 million tons in 2035.

For the four options, as well as for the continuation of the intra-EEA EU ETS alone as reference, we first show in Figure 3 and Table 5 the expected share of annual global $\mathrm{CO}_{2}$ air transport emissions subject to emission trading or offsetting, i.e., for which either offsets (CORSIA) or EUA (EU ETS) will have to be purchased and surrendered (emissions above cap/baseline). 


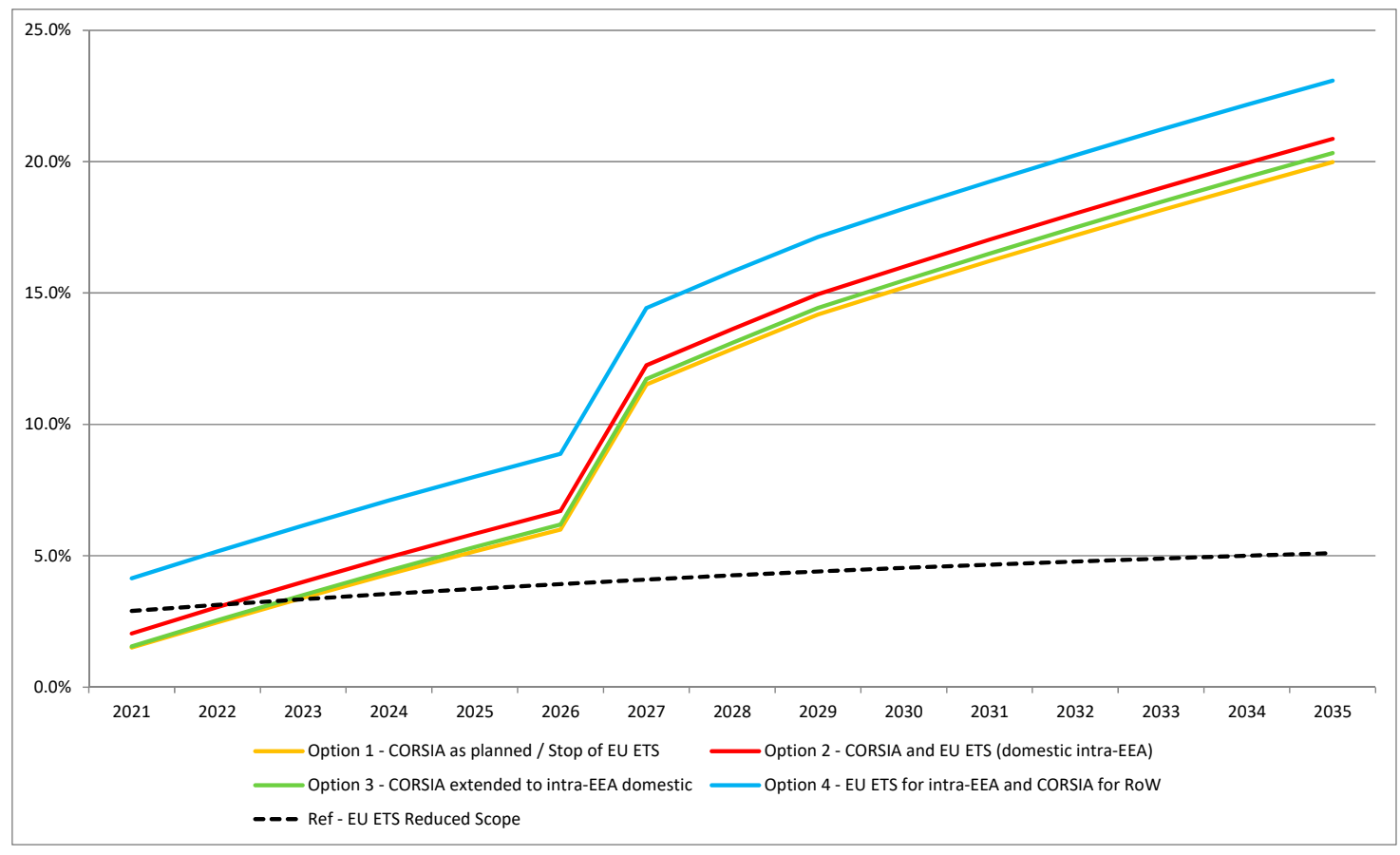

Figure 3. Shares of worldwide passenger air traffic $\mathrm{CO}_{2}$ emissions covered by trading/offsetting in the period 2020 to 2035 by option.

Table 5. Shares of worldwide passenger air traffic $\mathrm{CO}_{2}$ emissions covered by trading/offsetting in the period 2016 to 2035 by option.

\begin{tabular}{cccccc}
\hline Year & $\begin{array}{c}\text { Option } \\
\text { 1-CORSIA } \\
\text { Only }\end{array}$ & $\begin{array}{c}\text { Option } \\
\text { 2-CORSIA } \\
\text { EU ETS for } \\
\text { EEA Domestic }\end{array}$ & $\begin{array}{c}\text { O-CORSIA } \\
\text { 3-co for EEA } \\
\text { Domestic }\end{array}$ & $\begin{array}{c}\text { Option 4-EU ETS } \\
\text { for Intra-EEA and } \\
\text { CORSIA for RoW }\end{array}$ & $\begin{array}{c}\text { Ref-EU ETS } \\
\text { Reduced } \\
\text { Scope }\end{array}$ \\
\hline 2016 & & & & & $2.1 \%$ \\
2017 & & & & & $2.2 \%$ \\
2018 & & & & & $2.4 \%$ \\
2019 & & & & & $2.5 \%$ \\
2020 & & & & & $2.7 \%$ \\
2021 & $1.5 \%$ & $3.0 \%$ & $1.6 \%$ & $4.1 \%$ & $2.9 \%$ \\
2022 & $2.5 \%$ & $4.0 \%$ & $2.5 \%$ & $5.2 \%$ & $3.1 \%$ \\
2023 & $3.4 \%$ & $4.9 \%$ & $4.5 \%$ & $6.2 \%$ & $3.3 \%$ \\
2024 & $4.3 \%$ & $5.8 \%$ & $5.3 \%$ & $7.1 \%$ & $3.6 \%$ \\
2025 & $5.2 \%$ & $6.7 \%$ & $6.2 \%$ & $8.0 \%$ & $3.7 \%$ \\
2026 & $6.0 \%$ & $12.2 \%$ & $11.7 \%$ & $14 \%$ & $3.9 \%$ \\
2027 & $11.5 \%$ & $13.6 \%$ & $13.1 \%$ & $15.8 \%$ & $4.1 \%$ \\
2028 & $12 \% \%$ & $15.0 \%$ & $14.4 \%$ & $17.1 \%$ & $4.3 \%$ \\
2029 & $14.2 \%$ & $16.0 \%$ & $15.5 \%$ & $18.2 \%$ & $4.4 \%$ \\
2030 & $15 \%$ & $17.0 \%$ & $16.5 \%$ & $19.2 \%$ & $4.5 \%$ \\
2031 & $16.2 \%$ & $18.0 \%$ & $17.5 \%$ & $20.2 \%$ & $4.7 \%$ \\
2032 & $17.2 \%$ & $19.0 \%$ & $18.5 \%$ & $21.2 \%$ & $4.8 \%$ \\
2033 & $18 \%$ & $19.9 \%$ & $19.4 \%$ & $22.2 \%$ & $4.9 \%$ \\
2034 & $19.1 \%$ & $20.9 \%$ & $20.3 \%$ & $23.1 \%$ & $5.0 \%$ \\
2035 & $20.0 \%$ & & & & $5.1 \%$ \\
\hline
\end{tabular}

If continued in a non-CORSIA world, the EU ETS in its reduced scope would, over the years, tackle a slowly increasing share of emissions, from $2.1 \%$ in 2016 over $2.9 \%$ in 2021 to $5.1 \%$ in 2035 (dotted black line). This reflects the growing share of annual emissions above the EU ETS cap which, from 2021, will be further reduced by the linear reduction factor of $2.2 \%$ p.a. 
However, within just a few years after the start of CORSIA, both CORSIA alone and the assessed combinations of CORSIA and emission trading for intra-EEA or EEA domestic routes are expected to regulate a larger share of emissions than the EU ETS alone.

Hereby, the curves showing the shares of emissions subject to compensation by either CORSIA alone and by any combinations of CORSIA and the EU ETS run almost parallel. Obviously, with reduction shares of $1.5 \%$ in 2021, $11.5 \%$ in 2027, and 20\% in 2035, respectively, "CORSIA only" (Option 1; orange line in Figure 3) will affect a smaller share of worldwide $\mathrm{CO}_{2}$ emissions than any combination of CORSIA and the EU ETS. This is due to the lower, more ambitious EU cap and the inclusion of domestic flights in the EU ETS.

Option 3 (green line), which assumes a voluntary extension of CORSIA to EEA domestic flights while fully stopping the EU ETS for aviation, would only generate very limited additional environmental benefits compared to Option 1 (e.g., $1.6 \%$ vs. $1.5 \%$ in $2021,11.7 \%$ vs. $11.5 \%$ in 2027 , or $20.3 \%$ vs. $20.0 \%$ in 2035).

Interestingly, also Option 2 (continuation of the EU ETS for domestic intra-EU flights alongside CORSIA; red line) would only cover a slightly higher share of worldwide air transport emissions, at least in the long run. In the early years, due to the lower EU ETS cap, this option would cover a considerably higher share of emissions than CORSIA alone (e.g., $2.0 \%$ vs. $1.5 \%$ in 2021), but over the years this gap would decline in relative sense (e.g., $12.2 \%$ vs. $11.5 \%$ in 2027 , or $20.9 \%$ vs. $20 \%$ in 2035)-despite the linear reduction factor. The main reason for this relatively small additional benefit of maintaining the EU ETS for domestic EEA flights is the low expected growth rate of just $3.2 \%(2.9 \%)$ in this traffic area for the 2020-2029 (2030-2039) period.

The largest net effect could be achieved in maintaining the EU ETS for all intra-EEA flights, instead of CORSIA, and in applying the latter only to international routes which are not fully within the EEA (Option 4; blue line). Here, the compensation rates would increase to $4.1 \%$ vs. $1.5 \%$ in $2021,14.4 \%$ vs. $11.5 \%$ in 2027 , or $23.1 \%$ vs. $20.0 \%$ in 2035 , again compared to Option 1.

We have not modeled any possible airline supply or passenger demand reactions, like, e.g., the discontinuation of flights due to increased cost and lower demand resulting from either of the schemes. Such reactions are likely, but they would depend on the actual prices of EUA and CERs, on individual airline pricing strategies, and on the route-specific price elasticities of passenger demand, for which the estimates found in the literature show relatively large ranges [27].

The above results, however, do not acknowledge that there is a high likelihood that only a relatively small percentage of the nominal emission reduction will actually be achieved when investing in CORSIA CERs. Hence, these findings represented emissions subject to offsetting (and/or trading) rather than emissions actually reduced by offsetting and/or trading.

To better-and more realistically-show the actual environmental impact of the regulatory options, Table 6 and Figure 4 give an idea of the actual net reduction in air transport $\mathrm{CO}_{2}$ emissions. For this, based on the findings of [33] referred to in Section 2.3, we assume that CORSIA-CERs would, on average, only achieve a $20 \%$ net reduction of actual emissions.

If we assume CORSIA CERs to have, on average, an actual environmental effectiveness of only $20 \%$, the picture changes considerably. In the whole period until 2035, Options 1 (CORSIA only), 2 (CORSIA + domestic EU ETS), and 3 (extension of CORSIA to EEA domestic flights) would all deliver lower environmental benefits than a simple continuation of the EU ETS in its reduced scope (4.0\% to $4.9 \%$ reduction rate in 2035 compared to $5.1 \%$ for the EU ETS if continued in its current form). These findings massively question if CORSIA-introduced as a single market-based measure for international aviation-would have any environmental benefits compared to the European ETS. 
Table 6. Shares of worldwide passenger air traffic $\mathrm{CO}_{2}$ emissions reduced by trading/offsetting in the period 2016 to 2035 by option-Certified Emissions Reduction (CER) effectiveness assumption of $20 \%$.

\begin{tabular}{cccccc}
\hline Year & $\begin{array}{c}\text { Option } \\
\text { 1-CORSIA } \\
\text { Only }\end{array}$ & $\begin{array}{c}\text { 2-CoRSIA } \\
\text { EU ETS for } \\
\text { EEA Domestic }\end{array}$ & $\begin{array}{c}\text { Option } \\
\text { also for EEA } \\
\text { Domestic }\end{array}$ & $\begin{array}{c}\text { Option 4-EU ETS } \\
\text { for intra-EEA and } \\
\text { CORSIA for RoW }\end{array}$ & $\begin{array}{c}\text { Ref-EU ETS } \\
\text { Reduced } \\
\text { Scope }\end{array}$ \\
\hline 2016 & & & & & $2.1 \%$ \\
2017 & & & & & $2.2 \%$ \\
2018 & & & & & $2.4 \%$ \\
2019 & & & & & $2.5 \%$ \\
2020 & & & & & $2.7 \%$ \\
2021 & $0.3 \%$ & $1.1 \%$ & $0.3 \%$ & $3.1 \%$ & $2.9 \%$ \\
2022 & $0.5 \%$ & $1.3 \%$ & $0.7 \%$ & $3.5 \%$ & $3.1 \%$ \\
2023 & $0.7 \%$ & $1.5 \%$ & $0.9 \%$ & $3.9 \%$ & $3.3 \%$ \\
2024 & $0.9 \%$ & $1.7 \%$ & $1.1 \%$ & $4.3 \%$ & $3.7 \%$ \\
2025 & $1.0 \%$ & $1.9 \%$ & $1.2 \%$ & $4.9 \%$ & $3.9 \%$ \\
2026 & $1.2 \%$ & $3.0 \%$ & $2.3 \%$ & $6.2 \%$ & $4.1 \%$ \\
2027 & $2.3 \%$ & $3.3 \%$ & $2.6 \%$ & $6.6 \%$ & $4.3 \%$ \\
2028 & $2.6 \%$ & $3.6 \%$ & $2.9 \%$ & $6.9 \%$ & $4.4 \%$ \\
2029 & $2.8 \%$ & $3.8 \%$ & $3.1 \%$ & $7.3 \%$ & $4.5 \%$ \\
2030 & $3.0 \%$ & $4.1 \%$ & $3.3 \%$ & $7.6 \%$ & $4.7 \%$ \\
2031 & $3.2 \%$ & $4.3 \%$ & $3.5 \%$ & $8.9 \%$ & $4.8 \%$ \\
2032 & $3.4 \%$ & $4.5 \%$ & $3.7 \%$ & $8.4 \%$ & $5.9 \%$ \\
2033 & $3.6 \%$ & $4.7 \%$ & $3.9 \%$ & $8.7 \%$ & $5.0 \%$ \\
2034 & $3.8 \%$ & $4.9 \%$ & $4.1 \%$ & & \\
2035 & $4.0 \%$ & & & & \\
\hline
\end{tabular}

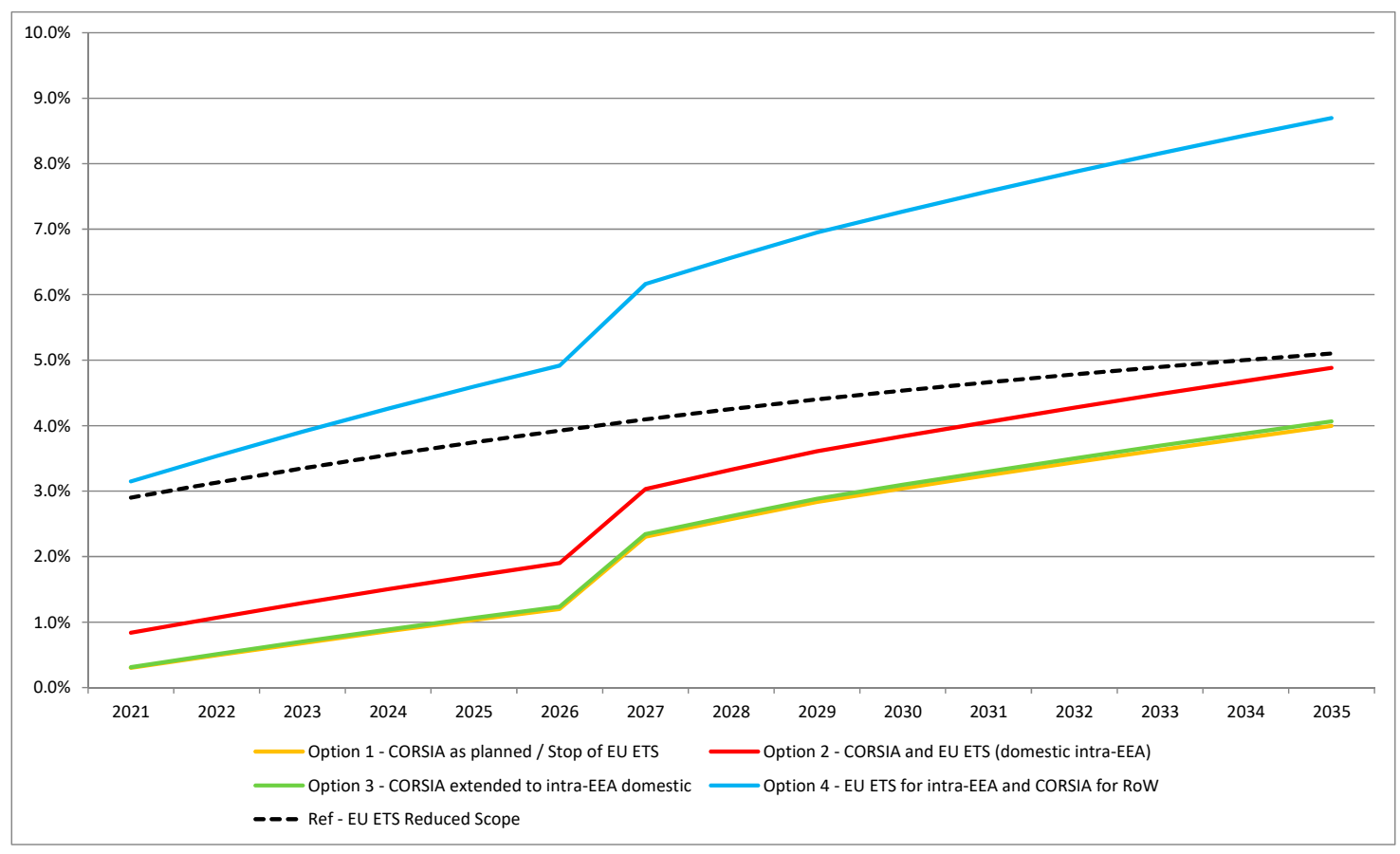

Figure 4. Shares of worldwide passenger air traffic $\mathrm{CO}_{2}$ emissions reduced by trading/offsetting in the period 2020 to 2035 by option-CER effectiveness assumption of $20 \%$.

The only noteworthy improvement in environmental effectiveness compared to the EU ETS alone would be achieved if EU ETS permanently replaced CORSIA on intra-EEA routes (Option 4). Again assuming a $20 \%$ effectiveness rate for CERs, such a move by the EU would help achieving a net reduction share of about $3.1 \%$ in $2021,6.2 \%$ in 2027 , and $8.7 \%$ in 2035 , respectively, compared to just 
$0.3 \%, 2.3 \%$, and $4.0 \%$ for CORSIA alone. However, such a step might be regarded as not to be in line with Annex 16, Volume IV, as, e.g., the International Air Transport Association (IATA) argues that "CORSIA was achieved on the condition that CORSIA would be the only market-based measure applied to international flights" [38].

\subsubsection{Results and Discussion-Impacts on Accumulated Emissions}

The annual reduction in emissions achieved by the assessed regulatory options is just one side of the story as climate change is a "stock" rather than just a "flow-problem" because the greenhouse effect, and eventually actual climate change, depend on the "stock", the concentration of $\mathrm{CO}_{2}$ and other greenhouse gases in the atmosphere. Hence, it is one key pillar of the UNFCCC Paris Agreement to "reach global peaking of greenhouse gas emissions as soon as possible", and to "undertake rapid reductions thereafter" [5].

To show the contribution of the air transport sector to the global emissions stock in absolute terms, Table 7 contains the cumulative amount of air transport net $\mathrm{CO}_{2}$ emissions over the timeframe 2021-2035, as well as cumulative reduction over this period. Again, we differentiate between the above policy options and between the $100 \%$ and $20 \%$ CORSIA CER effectiveness rate assumptions. In addition, the table provides cumulative emissions for the intra-EEA EU ETS (reference scenario) and for a "no measure" scenario.

Table 7. Accumulated passenger air traffic $\mathrm{CO}_{2}$ emissions and emission reduction until 2021 by option.

\begin{tabular}{|c|c|c|c|c|c|c|c|c|c|c|}
\hline \multirow{2}{*}{$\begin{array}{r}\begin{array}{c}\text { Period } \\
(2021\end{array} \\
\text { to ... }) \\
\text { CE }\end{array}$} & \multirow{2}{*}{$\begin{array}{c}\begin{array}{c}\text { No } \\
\text { measure } \\
\left(\mathrm{Mt} \mathrm{CO}_{2}\right)\end{array} \\
\text { effectiven }\end{array}$} & \multirow{2}{*}{$\begin{array}{l}\text { EU ETS } \\
\text { (ref) }(\mathrm{Mt} \\
\left.\quad \mathrm{CO}_{2}\right) \\
\text { rate }\end{array}$} & \multicolumn{2}{|c|}{$\begin{array}{c}\text { Option } 1 \\
\text { (CORSIA only) } \\
\left.(\mathrm{Mt} \mathrm{CO})^{2}\right)\end{array}$} & \multicolumn{2}{|c|}{$\begin{array}{c}\text { Option } 2 \\
\text { (CORSIA + EU } \\
\text { ETS domestic) } \\
\left(\mathrm{Mt} \mathrm{CO}_{2}\right)\end{array}$} & \multicolumn{2}{|c|}{$\begin{array}{c}\text { Option } 3 \text { (CORSIA } \\
\text { extension to EEA } \\
\text { domestic, no ETS) } \\
\left(\mathrm{Mt} \mathrm{CO}_{2}\right)\end{array}$} & \multicolumn{2}{|c|}{$\begin{array}{c}\text { Option } 4 \text { (EU } \\
\text { ETS for } \\
\text { intra-EEA and } \\
\text { CORSIA for } \\
\text { RoW) }\left(\mathrm{Mt} \mathrm{CO}_{2}\right)\end{array}$} \\
\hline & & & $100 \%$ & $20 \%$ & $100 \%$ & $20 \%$ & $100 \%$ & $20 \%$ & $100 \%$ & $20 \%$ \\
\hline 2021 & 887 & 861 & 874 & 884 & 869 & 880 & 873 & 884 & 850 & 859 \\
\hline 2022 & 1803 & 1749 & 1767 & 1796 & 1757 & 1786 & 1766 & 1796 & 1719 & 1743 \\
\hline 2023 & 2750 & 2664 & 2682 & 2736 & 2666 & 2720 & 2679 & 2736 & 2607 & 2652 \\
\hline 2024 & 3728 & 3607 & 3618 & 3706 & 3596 & 3684 & 3614 & 3705 & 3516 & 3589 \\
\hline 2025 & 4739 & 4580 & 4577 & 4707 & 4548 & 4678 & 4572 & 4706 & 4446 & 4554 \\
\hline 2026 & 5784 & 5585 & 5559 & 5739 & 5523 & 5703 & 5552 & 5738 & 5399 & 5547 \\
\hline 2027 & 6865 & 6621 & 6515 & 6795 & 6471 & 6751 & 6506 & 6793 & 6323 & 6561 \\
\hline 2028 & 7982 & 7691 & 7489 & 7884 & 7436 & 7831 & 7477 & 7881 & 7264 & 7606 \\
\hline 2029 & 9138 & 8796 & 8481 & 9007 & 8419 & 8945 & 8466 & 9004 & 8222 & 8681 \\
\hline 2030 & 10326 & 9930 & 9488 & 10158 & 9417 & 10087 & 9470 & 10155 & 9193 & 9782 \\
\hline 2031 & 11546 & 11093 & 10510 & 11339 & 10430 & 11258 & 10489 & 11335 & 10179 & 10910 \\
\hline 2032 & 12801 & 12288 & 11549 & 12550 & 11458 & 12459 & 11524 & 12545 & 11179 & 12066 \\
\hline 2033 & 14090 & 13514 & 12605 & 13793 & 12502 & 13691 & 12575 & 13787 & 12195 & 13250 \\
\hline 2034 & 15415 & 14773 & 13677 & 15068 & 13563 & 14954 & 13644 & 15061 & 13227 & 14464 \\
\hline 2035 & 16778 & 16066 & 14767 & 16376 & 14642 & 16250 & 14729 & 16368 & 14275 & 15708 \\
\hline \multicolumn{2}{|c|}{$\begin{array}{c}\text { Cumulative } \\
\text { reduction compared } \\
\text { to "no measure" }\end{array}$} & 712 & 2011 & 402 & 2136 & 528 & 2049 & 410 & 2503 & 1070 \\
\hline
\end{tabular}

In total, over the period 2021-2035, cumulative passenger air transport $\mathrm{CO}_{2}$ emissions are expected to reach almost $16,800 \mathrm{Mt}$.

If the EU ETS stayed in operation but without CORSIA, this amount would be reduced by $712 \mathrm{Mt}$. CORSIA alone, as envisaged by ICAO, would achieve a cumulative reduction by $402 \mathrm{Mt}$ if an average CER effectiveness rate of $20 \%$ is assumed.

As the overall reduction of emissions that would be generated by Options 2 (maintaining the EU ETS for domestic operations) and 3 (voluntary extension of CORSIA to domestic intra-EEA flights) is also expected to remain below the environmental contribution of the EU ETS alone (528 and 410 $\mathrm{Mt}$, respectively), the only option for the EU to increase the environmental effectiveness of CORSIA beyond EU ETS levels would be to Option 4, i.e., a permanent replacement of CORSIA on intra-EEA routes by the EU ETS. 


\subsection{MRV implications}

Common rules regarding MRV are crucial both for the EU ETS and for CORSIA, to ensure that the schemes' implementation and handling do not differ between countries and airlines. Key actors are the aircraft operators (AO), the competent authorities (CA), and the verifiers. Both the EU ETS and CORSIA require both one-off and annual MRV tasks during the compliance cycle which is, exemplarily for the EU ETS, illustrated in Figure 5:

- The main one-time task is the preparation (AO), check (CA), and approval (CA) of monitoring plans. This usually happens once for each aircraft operator under each of the schemes, be it when the MBM is introduced, or in case a new carrier joins the measure, or if there are any significant changes, such as the fuel estimation methodology, IT systems of relevance, or the organizational structure [39]. For the EU ETS, Article 14(2) of the "Monitoring and Reporting Regulation (MRR)" EU No 601/2012 [40] includes a minimum list of the typical changes which would require an update of the monitoring plan;

- During the compliance cycle, each AO has to compile an annual emissions report for the preceding year and provide it to its $C A$, together with a verification report prepared by a verifier;

- The CA is required to ensure that the emissions have been monitored and reported in accordance with the legislation (e.g., the MRR for the EU ETS). It will perform full or spot checks and may request an improvement report or start legal action.

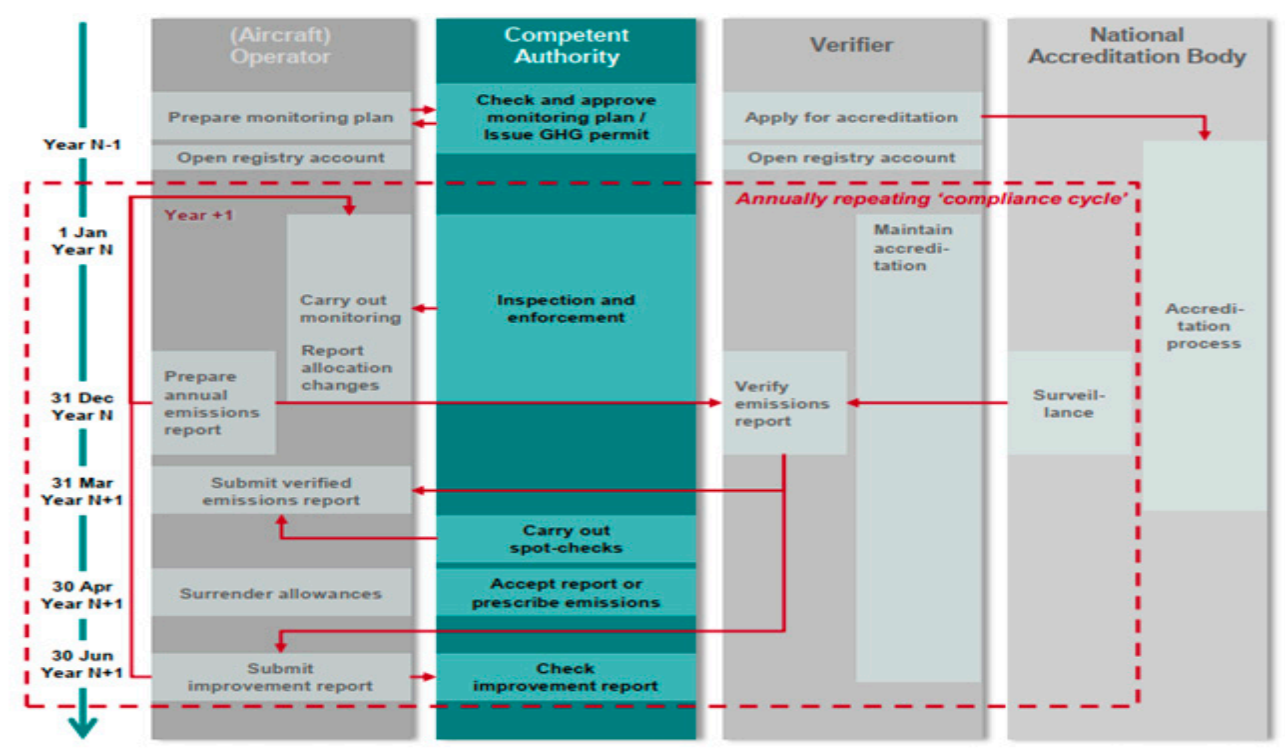

Figure 5. Compliance cycle of the EU ETS for aviation. Source: [41].

These MRV activities induce transaction costs both at the CA and AO levels. Costs of meeting the regulatory requirements will largely depend on the scope and type of the operation (e.g., scheduled flights by the same aircraft types on the same routes vs. ad-hoc operations of, e.g., business jet operators) and on the operators' internal processes.

At first sight, the MRV processes of the EU ETS and CORSIA seem very similar, but we observe fundamental differences in detail, such as the following issues [42]:

- Technical exemptions, especially regarding exempted flight categories, aircraft types, routes, and operators;

- Eligible fuel monitoring methods and thresholds for simplified monitoring methods;

- MRV for flights between non-EEA countries: Mandatory under CORSIA but voluntary in the according to the delegated regulation; 
- Country of accreditation of verifiers.

As a consequence, if both systems were running in parallel (Options 2 and 4), airlines would be required to monitor, report, and verify their emissions according to two different MRV systems, which would cause additional administrative effort despite relatively limited additional environmental benefits in the long run.

For EU carriers, this additional administrative burden was, however, softened by the Commission's delegated regulation for the implementation of CORSIA [33], which basically applies EU ETS MRV requirements for European operators to CORSIA. Non-EEA carriers, which provide intra-EEA services subject to the EU ETS in Options 2 and 4, would have to deal with two different regimes, though. This is because they would have to report their CORSIA emissions to their national CA (according to Annex 16, Volume IV) and their intra-European emissions subject to the EU ETS to their responsible CA in Europe, in accordance with the MRR requirements of the EU ETS. A more practical solution could be to fully apply CORSIA MRV to the EU ETS.

\section{Summary and Conclusions}

Although they belong both to the group of market-based measures aiming at reducing aviation's climate impact, CORSIA and the EU ETS for aviation are not directly comparable, as both their approaches (offsetting versus emission trading) and their geographical applications and baseline/cap differ. On paper, CORSIA is expected to net-reduce some $75-80 \%$ of the worldwide air transport emission growth on international routes, albeit only from the 2019-2020 baseline period. In addition, there are serious concerns about the environmental effectiveness of the CORSIA CERs. In contrast, the EU ETS includes EEA domestic air transport and has a much earlier cap $195 \%$ of average 2004-2006 emissions), which means that a higher share of emissions is actually capped, but only within Europe (EEA).

Especially in the early 2020s, when the emission growth under CORSIA will still be low, a consideration of emissions from domestic intra-EEA routes and the more ambitious cap of the EU ETS would play a significant role. Thus, the overall environmental effectiveness (also with regard to national and EU climate goals) of the measures would increase if the EU ETS stayed in operation, be it for intra-EU domestic flights or even for all intra-EU routes, replacing CORSIA there as an equivalent measure. Another option to increase the scope of CORSIA at least to some extent could be to voluntarily extend it to domestic EEA flights. If an environmental effectiveness of the CORSIA CERs of just $20 \%$ is assumed, the additional contribution of keeping the EU ETS in operation will be even larger. For this scenario, a continuation of the intra-European EU ETS in addition to the introduction of CORSIA on other international routes—against likely political resistance at ICAO-level—would result in a cumulative emission reduction in the period 2021-2035 by about $1070 \mathrm{Mt} \mathrm{CO}_{2}$, while CORSIA alone (without the EU ETS) would just achieve a reduction by some $400 \mathrm{Mt}$. In addition, a potential inclusion of non- $\mathrm{CO}_{2}$ effects is likely to happen much quicker within an EU ETS than at the global (CORSIA) level.

Administrative-wise, with regard, for example, to exemptions and eligible fuel monitoring methods, the CORSIA MRV system as specified in Annex 16, Vol. IV, could be applied to the EU ETS to reduce transaction costs and to assure similar or even identical MRV standards worldwide. However, the EU seems to go its own way as it plans to implement CORSIA not in accordance with Annex 16, Volume IV, but in line with the EU ETS MRV requirements.

Author Contributions: Conceptualization, S.M., W.G., and J.S.; methodology, W.G., M.J., S.M., and J.S.; software, M.J., validation, S.M., J.S., and W.G.; formal analysis, S.M.; resources, S.M. and J.S.; data curation, W.G. and M.J.; writing-original draft preparation, S.M. and J.S.; writing—review and editing, S.M., J.S., and W.G., visualization, S.M. and W.G.

Funding: This research received no external funding. 
Acknowledgments: We are grateful for the helpful comments we received after our presentation at the 2019 ATRS world conference in Amsterdam and from the two anonymous reviewers. Any remaining errors and analytical shortcomings remain the sole responsibility of the authors.

Conflicts of Interest: The authors declare no conflict of interest.

\section{References}

1. Intergovernmental Panel on Climate Change (IPCC). Aviation and the Global Atmosphere; A Special Report of IPCC Working Groups I and III; Cambridge University Press: Cambridge, UK, 1999; Available online: http://www.grida.no/climate/ipcc/aviation/index.htm (accessed on 8 May 2019).

2. Lee, D.S.; Fahey, D.W.; Forster, P.M.; Newton, P.J.; Wit, R.C.; Lim, L.L.; Owen, B.; Sausen, R. Aviation and global climate change in the 21st century. Atmos. Environ. 2009, 43, 3520-3537. [CrossRef]

3. International Energy Agency (IEA). CO2 Emissions from Fuel Combustion (Excel Database). 2017. Available online: https://www.iea.org/media/statistics/CO2Highlights.XLS (accessed on 22 January 2019).

4. Airbus. Global Networks, Global Citizens. Global Market Forecast, 2018-2037. 2018. Available online: https: //www.airbus.com/content/dam/corporate-topics/publications/media-day/GMF-2018-2037.pdf (accessed on 8 May 2019).

5. United Nations Framework Convention on Climate Change (UNFCCC). Adoption of the Paris Agreement, Conference of the Parties, Twenty-First Session (COP 21); United Nations Framework Convention on Climate Change: Paris, France, 2015; Available online: http://unfccc.int/resource/docs/2015/cop21/eng/109r01.pdf (accessed on 24 May 2019).

6. United Nations Framework Convention on Climate Change (UNFCCC). Kyoto Protocol to the United Nations Framework Convention on Climate Change. 1997. Available online: http://unfccc.int/resource/docs/ convkp/kpeng.pdf (accessed on 8 May 2019).

7. International Civil Aviation Organisation (ICAO). Resolution A39-3: Consolidated Statement of Continuing ICAO Policies and Practices Related to Environmental Protection-Global Market-based Measure (MBM) Scheme; International Civil Aviation Organisation: Montréal, QC, Canada, 2016; Available online: https://www.icao. int/environmental.../resolution_a39_3.pdf (accessed on 8 May 2019).

8. Preston, H.; Lee, D.S.; Hooper, P.D. The inclusion of the aviation sector within the European Union's Emissions Trading Scheme: What are the prospects for a more sustainable aviation industry? Environ. Dev. 2012, 2, 48-56. [CrossRef]

9. European Union (EU). Directive 2008/101/EC of the European Parliament and the Council of 19 November 2008 amending Directive 2003/87/EC so as to Include Aviation Activities in the Scheme for Greenhouse Gas Emission Allowance Trading within the Community. Off. J. Eur. Union 2009, 8, 3-21. Available online: https://eur-lex.europa.eu/legal-content/EN/TXT/PDF/?uri=CELEX:32008L0101\&from=EN (accessed on 8 May 2019).

10. European Union (EU). Directive 2009/29/EC of the European Parliament and of the Council Amending Directive 2003/87/EC so as to Improve and Extend the Greenhouse Gas Emission Allowance Trading System of the Community. Off. J. Eur. Union 2009, 140, 63-87. Available online: https://eur-lex.europa.eu/legalcontent/EN/TXT/PDF/?uri=CELEX:32009L0029\&from=EN (accessed on 8 May 2019).

11. European Commission. The EU Emissions Trading System (EU ETS). 2016. Available online: https: //ec.europa.eu/clima/sites/clima/files/factsheet_ets_en.pdf (accessed on 8 May 2019).

12. European Commission. Reducing Emissions from Aviation. 2019. Available online: https://ec.europa.eu/ clima/policies/transport/aviation_en\#tab-0-2 (accessed on 8 May 2019).

13. Anger, A.; Köhler, J. Including aviation emissions into the EU ETS: much ado about nothing? A review. Transport Pol. 2010, 17, 38-46. [CrossRef]

14. Scheelhaase, J.; Schaefer, M.; Grimme, W.; Maertens, S. Cost impacts of the inclusion of air transport into the European Emissions Trading Scheme in the period 2012-2020. Eur. J. Transp. Infrastruct. Res. 2012, 12, 332-348.

15. European Commission. Allocation to Aviation. 2019b. Available online: https://ec.europa.eu/clima/policies/ ets/allowances/aviation_en (accessed on 8 May 2019). 
16. European Union (EU). Regulation (EU) 2017/2392 of the European Parliament and of the Council of 13 December 2017 amending Directive 2003/87/EC to continue current limitations of scope for aviation activities and to prepare to implement a global market-based measure from 2021. Off. J. Eur. Union 2017, 350, 7-14. Available online: https://eur-lex.europa.eu/legal-content/EN/TXT/PDF/?uri=CELEX:32017R2392\&from=EN (accessed on 8 May 2019).

17. Bartels, L. The WTO legality of the application of the EU's emission trading system to aviation. Eur. J. Int. Law 2012, 23, 429-467. [CrossRef]

18. European Parliament. Briefing, EU Legislation in Progress, $\mathrm{CO}_{2}$ Emissions from Aviation. 2018. Available online: http://www.europarl.europa.eu/RegData/etudes/BRIE/2017/603925/EPRS_BRI(2017)603925_EN.pdf (accessed on 8 May 2019).

19. European Union (EU). Decision No 377/2013/EU of the European Parliament and of the Council of 24 April 2013 Derogating Temporarily from Directive 2003/87/EC Establishing a Scheme for Greenhouse Gas Emission Allowance Trading within the Community. Off. J. Eur. Union 2013, 113, 1-4. Available online: https://eur-lex.europa.eu/legal-content/EN/TXT/PDF/?uri=CELEX:32013D0377\&from=EN (accessed on 8 May 2019).

20. Albers, S.; Bühne, J.A.; Peters, H. Will the EU ETS instigate airline network reconfigurations? J. Air Transp. Manag. 2009, 15, 1-6. [CrossRef]

21. Scheelhaase, J. How to regulate aviation's full climate impact as intended by the EU council from 2020 onwards. J. Air Transp. Manag. 2019, 75, 68-74. [CrossRef]

22. International Civil Aviation Organisation (ICAO). Annex 16 to the Convention on International Civil Aviation, Environmental Protection; Carbon Offsetting and Reduction Scheme for International Aviation (CORSIA): Montréal, QC, Cananda, 2018; Volume IV.

23. International Civil Aviation Organisation (ICAO). Top 3 Misconceptions about CORSIA. 2019a. Available online: https://www.icao.int/environmental-protection/Pages/A39_CORSIA_FAQ6.aspx (accessed on 8 May 2019).

24. International Civil Aviation Organisation (ICAO). CORSIA States for Chapter 3 State Pairs. 2019b. Available online: https://www.icao.int/environmental-protection/CORSIA/Pages/state-pairs.aspx (accessed on 30 August 2019).

25. Hedley, A.; Rock, N.; Zaman, P. First Ever Global Regime for Aviation Emissions: ICAO Adopts Global Market-Based Measure to Combat Aircraft $\mathrm{CO}_{2}$ Emissions. Reed Smith Client Alerts. 10 October 2016. Available online: https:/www.reedsmith.com/en/perspectives/2016/10/first-ever-global-regime-for-aviationemissions-ic (accessed on 8 May 2019).

26. Schep, E.; van Velzen, A.; Faber, J. A Comparison between CORSIA and the EU ETS for Aviation. Delft. 2016. Available online: https://www.transportenvironment.org/sites/te/files/publications/2016_12_CE_Delft_ETS_ CORSIA_final.pdf (accessed on 8 May 2019).

27. Scheelhaase, J.; Maertens, S.; Grimme, W.; Jung, M. EU ETS versus CORSIA-A critical assessment of two approaches to limit air transport's $\mathrm{CO}_{2}$ emissions by market-based measures. J. Air Transp. Manag. 2018, 67, 55-62. [CrossRef]

28. Gold Standard. A Higher Standard for Climate Security and Sustainable Development. 2019. Available online: https://www.goldstandard.org/impact-quantification/gold-standard-global-goals (accessed on 30 August 2019).

29. Carbon Market Watch. Additionality \& Baselines. 2012. Available online: https://carbonmarketwatch.org/ 2012/05/30/additionality-and-baselines/ (accessed on 30 August 2019).

30. Greenair Communications. ICAO Council Approves Criteria for CORSIA Emissions Units and structure for New Body Overseeing Eligibility. 6 March 2019. Available online: https://www.greenaironline.com/news. php?viewStory=2573 (accessed on 8 May 2019).

31. Larsson, J.; Elofsson, A.; Sterner, T.; Akerman, J. International and national climate policies for aviation: a review. Climate Pol. 2019, 19, 787-7099. Available online: https://doi.org/10.1080/14693062.2018.1562871 (accessed on 24 May 2019). [CrossRef]

32. Timperley, J. CORSIA: The UN's Plan to 'Offset' Growth in Aviation Emissions after 2020. Carbon Brief 04.02.2019. Available online: https://www.carbonbrief.org/corsia-un-plan-to-offset-growth-in-aviationemissions-after-2020 (accessed on 24 May 2019). 
33. Cames, M.; Harthan, R.O.; Füssler, J.R.; Lazarus, M.; Lee, C.M.; Erickson, P.; Spalding-Fecher, R. How Additional is the Clean Development Mechanism? Analysis of the Application of Current Tools and Proposed Alternatives (No. CLIMA.B.3/SERl2013/0026r); Öko-Institut: Berlin, Germany, 2016; Available online: https: //ec.europa.eu/clima/sites/clima/files/ets/docs/clean_dev_mechanism_en.pdf (accessed on 8 October 2019).

34. European Commission. Commission Delegated Regulation (EU) ... /... of 6.3.2019 Supplementing Directive 2003/87/EC of the European Parliament and of the Council as Regards Measures adopted by the International Civil Aviation Organisation for the Monitoring, Reporting and Verification of Aviation Emissions for the Purpose of Implementing a Global Market-Based Measure. 2019c. Available online: https://eur-lex.europa. eu/legal-content/EN/TXT/PDF/?uri=PI_COM:C(2019)1644\&from=EN (accessed on 8 May 2019).

35. Van Velzen. CORSIA, EU ETS and the EU2030 Aviation Emissions Target. Report prepared for Transport and Environment (T\&E). Report nr 18-13. 2018. Available online: https://www.transportenvironment.org/sites/te/files/publications/2018_09_Study_CORSIA_EU_ETS_ and_EU2030_aviation_emissions_target_Final.pdf (accessed on 30 August 2019).

36. Team_Play. AERO-MS. 2013. Available online: https://trimis.ec.europa.eu/sites/default/files/project/ documents/20130218_181700_44187_TeamPlay_ToolDescriptionAEROMS.pdf (accessed on 23 May 2019).

37. International Civil Aviation Organisation (ICAO). FESG Traffic and Fleet Forecasts—Methodological Paper; Unpublished Working Paper; International Civil Aviation Organisation: Montreal, QC, Cananda, 3 June 2014.

38. International Air Transport Association (IATA). Fact Sheet: CORSIA and Carbon Pricing, 12 May 2019. Available online: https://www.iata.org/policy/environment/Documents/corsia-factsheet-carbon-pricing.pdf (accessed on 8 October 2019).

39. European Commission. Guidance Document, The Monitoring and Reporting Regulation - General guidance for Aircraft Operators, MRR Guidance document No. 2, Updated Version, 11 January 2018. Directorate-General Climate Action, Directorate C-Climate Strategy, Governance and Emissions from non-trading sectors, Unit C.2-Governance and Effort Sharing. Available online: https://ec.europa.eu/clima/ sites/clima/files/ets/monitoring/docs/gd2_guidance_aircraft_en.pdf (accessed on 30 August 2019).

40. European Union (EU). Commission Regulation (EU) No 601/2012 of 21 June 2012 on the monitoring and reporting of greenhouse gas emissions pursuant to Directive 2003/87/EC of the European Parliament and of the Council. Off. J. Eur. Union 2012, 181, 30-104. Available online: https://eur-lex.europa.eu/legal-content/ EN/TXT/PDF/?uri=CELEX:32012R0601\&from=EN (accessed on 30 August 2019).

41. European Commission. EU ETS Monitoring, Reporting, Verification and Accreditation-Quick guide for Competent Authorities, Version of 9 November 2017. Directorate-General Climate Action, Directorate C-Climate Strategy, Governance, and Emissions from Non-Trading Sectors, CLIMA.C.2-Governance \& Effort Sharing. Available online: https:/ec.europa.eu/clima/sites/clima/files/ets/monitoring/docs/quick_ guide_ca_en.pdf (accessed on 30 August 2019).

42. International Air Transport Association (IATA). Comments on the Commission's Draft Delegated Regulation on Reporting Measures to Implement CORSIA. 12 December 2018. Available online: https://ec.europa.eu/ info/law/better-regulation/feedback/15893/attachment/090166e5c002b4cc_it (accessed on 8 May 2019).

(C) 2019 by the authors. Licensee MDPI, Basel, Switzerland. This article is an open access article distributed under the terms and conditions of the Creative Commons Attribution (CC BY) license (http://creativecommons.org/licenses/by/4.0/). 